УДК: 316.776-053.6(497.11)

81'22:316.776-053.6(497.11)

https://doi.org/10.18485/kij.2017.64.1_2.8

ВИОЛЕТА Р. КЕЦМАН*

Пета београдска гимназија Београд
Оригинални научни рад

Примљен: 11.03.2017.

Прихваћен: 15.04.2017.

\title{
ТРАНСФОРМАЦИЈЕ ЈЕЗИЧКОГ ЗНАКА У ДИГИТАЛНОЈ КОМУНИКАЦИЈИ АДОЛЕСЦЕНАТА
}

\begin{abstract}
Циљ рада је утврђивање промена на које наилази језички знак у дигиталној комуникацији адолесцената. Рад обухвата теоријско разматрање о језичком знаку у дигиталном окружењу и емпиријско истраживање спроведено са ученицима Пете београдске гимназије. Покушано је да се одговори на питања: која су обележја језичког знака у свакодневној дигиталној комуникацији младих, као и да ли су промене у начину бележења знака (писање-брзо куцање) условиле и промену његове семиотичке структуре. У спроведеном истраживању коришћена је метода испитивања, технике групни интервју информативног карактера и упитник са питањем отвореног типа. Предмет истраживања представљају скраћенице у дигиталном дискурсу. Резултати показују да су скраћенице из енглеског језика језички знак којим се адолесценти у дигиталној комуникацији у највећој мери користе. Потврђено је да се промене на језичком знаку у дигиталној комуникацији адолесцената врше на нивоу означитеља - редукцији, економичности, селективности одступању од ортографске норме.
\end{abstract}

Кључне речи: језички знак, дигитална комуникација, дигитални медији, скраћенице, инсуфицијенција, адолесценти.

\section{1. Увод}

У средишту дигиталне културе с почетка 21. века налази се модерно друштво, чији идентитет обликује неколико аксиома: нове информационе технологије проистекле из хладног рата, глобализација, авангардне уметничке праксе, контракултурни техноутопизам. У тако организованом свету егзистенцију јединке детерминишу брзина, емоционална, временска и језичка економичност. Појава нових информационих технологија условила је свакодневно коришћење дигиталних медија ${ }^{1}$ у интерперсоналној комуникацији. Због своје графемске ус-

\footnotetext{
"violetakecmann@gmail.com

${ }^{1}$ Под појмом „дигитални медији” подразумевамо електронске медије (радио и телевизија) и нове облике информационих и комуникационих платформи, којима приступамо путем савремених информационих технологија (рачунар, смартфон).
} 
ловљености и масовности које омогућавају нове информационе технологије, дигитална комуникација ${ }^{2}$ пружа могућност обичном појединцу да свакодневно партиципира у креирању означитеља знака којим се користи. Неплански и без учешћа свесне воље, појединац свакодневно бива „изазиван” да на глобалној платформи нових медија потврди своје присуство у датом историјском тренутку. Он то и чини, интервенишући у већој или мањој мери на нивоу означитеља језичког знака (скраћивањем речи и израза, вишезначношћу, економисањем, селективношћу и кршењем ортографске норме).

Рад обухвата интердисциплинарно теоријско разматрање са аспеката лингвистике, анализе дискурса, семиотике, социологије, комуникологије, критике и естетике медија, као и емпиријско истраживање спроведено са ученицима Пете београдске гимназије. Методолошки оквир је квалитативни и квантитативни. Хипотезе од којих се пошло су следеће:

1.1. У свакодневној дигиталној комуникацији језички знак је значајно измењен (трансформисан) у односу на језички знак употребљен у комуникацији која није дигитална ${ }^{3}$.

1.2. Трансформације језичког знака односе се на промене означитеља - интензивирање редукције, економичности, селекције, експанзију скраћеница и одступање од ортографске норме.

У спроведеном емпиријском истраживању коришћена је метода испитивања, технике групни интервју информативног карактера и упитник са питањем отвореног типа. Подаци су статистички обрађени мерама пребројавања (фреквенција, проценат). За циљну групу одабрани су адолесценти ${ }^{4}$, као најактивнији корисници интернета у свакодневној комуникацији 5 .

\section{2. Инсуфицијенција језичког знака у дигиталној комуникацији}

Човекова нужност је да гради и употребљава знаковне системе, стављајући у њихов центар сопствену имагинативну способност. Језик је катализатор имагинације, на коју делује подстицајним импулсима више него готовим схемама (Перс/ Peirce у Симић 1991: 24). Језик нужно мора да одговори на задатак да помоћу ограниченог и малог броја гласовних јединица изрази мноштво различитих идеја. Дефицитарност, инсуфицијенција израза у односу на садржај је-

${ }^{2}$ Под појмом „дигитална комуникација” подразумевамо дигиталне медије у ширем смислу - савремене информационе технологије (рачунар, смартфон) и друштвене мреже (вајбер/ viber, феjсбук/ Facebook, Твитер/ Twiter, Инстаграм/ Instagram).

${ }^{3}$ Писаној и усменој

${ }^{4}$ Истраживањем су обухваћени старији адолесценти, узраста од 18 и 19 година.

${ }^{5}$ Под појмом „свакодневна комуникација” обухваћена је неформална редовна комуникација, насупрот пословној комуникацији, чији учесници такође редовно комуницирају путем модерних информационих технологија (рачунара, смартфона) и интернет мрежа (социјалних мрежа, вајбера, инстаграма итд.). 
зика, условила је амбигвитет језика, о којем говоре Јакобс (Jacobs) и Розенбаум (Rosenbaum) у студији Трансформација, стил и мишљење. ${ }^{6}$

„Једно и исто основно значење може бити исказано уз помоћ више форми. Али и једна форма може постати обележје више значења. Амбигвитет је универзална особина језика.” (Јакобс, Розенбаум 1971: 3)

Инсуфицијенција језичког знака у дигиталној комуникацији огледа се у интензивној економичности, селективности и редукцији.

\section{1. Економичност}

Појам економичност односи се на потребу за уштедом, економисањем изразом. Позивајући се на један Зипфов (Zipf) радㄱ, Андре Мартине (A. Martine) je развио теорију о језичкој економији као равнотежи између два „антиномична” чиниоца: с једне стране потребе за комуникацијом и потребе говорника да пренесе своју поруку и, са друге, принципа најмањег напора, због кога он смањује произвођење менталне и физичке енергије на минимум довољан за остварење намере. (Мартине 1973: 162). У контексту комуникације у дигиталној култури, економичност се потврђује у суженој лексици и устаљеним језичким обрасцима поруке, које дигитална технологија у готовој форми нуди (устаљени изрази, емотикони). Модерни корисник језичког знака је приступио начину који не захтева менталну и физичку енергију за сусрет са говорником, већ умреженост на интернету, механички мануелни рад (куцање поруке), смартфон или рачунар, вештину њиховог коришћења као новог „фонолошког апарата” и савладану елементарну писменост.

\section{2. Селективност}

Уместо да исцрпљује све могућности и ресурсе који су му на располагању, сваки језик се користи само једном њиховим делом, док његов значајан део остаје пасиван. Лингвиста Радоје Симић запажа да се у семиолошком простору ова појава лако открива на плану израза, али је њено постојање неоспорно и на плану садржаја. Он истиче да ,језички колектив, а следствено томе и појединац, прави известан избор, одбацујући један њен део.” (Симић 1991: 136)

Селективност као обележје језичког знака у дигиталној култури може се довести у везу са глобализацијом у корист енглеског језика. Најактивнији део лексике у дигиталној комуникацији изведен је, или у потпуности преузет, из енглеског језика. ${ }^{8}$

${ }^{6}$ Transformation, Style and Meaning, Roderick A. Jacobs [and] Peter S. RosenbaumWaltham, Mass: Xerox College Pub, 1971.

${ }^{7}$ Human Behavior and the Principle of Least Effort, G. K. Zipf, Cambridge/Mass, 1949.

${ }^{8}$ Енглеским језиком се људи данас служе више него иједним другим језиком у историји (око две милијарде људи или трећина светског становништва). Дејвид Кристал у вези са тим запажа: „Језик постаје глобални само из једног разлога, а то је моћ његових говорника. У протекла четири века енглески је растао упоредо с политичком и војном моћи Британског царства, а онда, да тако кажем, 


\section{3. Редукција језичке грађе}

Енглески лингвиста Џон Лајонс (John Layons) подсећа на честу појаву у језику, коју назива „контекстуализација”, а која се тиче односа експлициране грађе на нивоу израза и количине информације:

„Разговор који би се у целини састојао од граматички потпуних реченица, био би, као текст уопште, неразумљив. Саставни део језичке компетенције говорника једног језика јесте његова способност да продукује граматички непотпуне, али контексту прилагођене реченичне фрагменте”. (Лајонс 1983: 157)

У комуникацији путем модерних информационих технологија, редукција језичког израза је опште место. У значајној мери редукција је присутна и на пољу интерпункције, што је условило или потпуни изостанак знакова интерпункције, или њихову сведеност на један интерпункцијски знак - тачку.

Упркос чињеници да промене на означитељу могу довести до шума у комуникацији и привидно прекинути везу са некадашњом знаковном структуром, однос означитеља и означеног и даље је део конвенције. У том случају реч је о имплицитној конвенцији. ${ }^{9}$ Значење је у већој или мањој мери увек кодирано. Кодирање је ствар договора између корисника знака који признаје однос између означитеља и означеног и уважава га приликом употребе знака (Гиро/ Guiraud 1975: 29). Гиро запажа да употреба одређује и растеже конвенцију, „док се знак кодира, знак се може и декодирати" (Гиро 1975: 29). Због тога ћемо промене на означитељу, које су последица инсуфицијенције знака у дигиталној комуникацији, посматрати као део процеса кодирања.

\section{4. Скраћивање речи}

Висока инсуфицијенција језичког знака у дигиталној комуникацији младих јавља се као последица промена у психолошком и културолошком детерминисању сопственог идентитета у дигиталној култури. У сфери дигиталне интерперсоналне комуникације адолесцената, ова појава се потврђује у израженој продуктивности и употреби скраћеница. Експанзија скраћеница у дигиталној комуникацији почела је са широм употребом Ес-Ем-Еса ${ }^{10}$ (SMS-a) на преласку из 20. у 21. век.

\footnotetext{
и 'америчког царства'. Друго, знање је постало моћ - дошло је до индустријске револуције коју су извели говорници енглеског. Треће, ту је и раст економске моћи у XIX веку - прве светске банкарске системе су стварали углавном људи са англосаксонског и немачког говорног подручја. Најзад, можемо говорити и о моћи у културном погледу: управо је енглески језик поспешио културни развој човечанства у XX веку. Интернет је некада био у потпуности на енглеском. Енглески је држао филм, Холивуд, контролне торњеве на аеродромима, маркетинг.. свуда је био енглески, енглески и само енглески. Из свих ових разлога, он је постао доминантна сила нашег доба.” (Кецман, Милошевић, Ћећез-Иљукић 2013: 15).

${ }^{9}$ Насупрот имплицитне конвенције стоји експлицитна конвенција.

${ }^{10}$ Short Messaging Service
} 
Скраћенице су настале из потребе да се при писању уштеди у простору и времену. У Правопису Матице српске стоји да скраћивање речи „не би смело ићи на штету брзог читања и разумевања текста" (Пешикан, Јерковић, Пижурица 2010: 144). Овај захтев условљава постојање одређених правила која обезбеђују остваривање комуникативне функције скраћеница.

\footnotetext{
„Општа је препорука да у скраћивању речи треба бити уздржан, а по правилу би требало скраћивати речи чије је појављивање у одређеном тексту често или предвидљиво" (Пешикан, Јерковић, Пижурица, 144, т. 178).
}

Правила скраћивања утврђена су обичајима у језичкој пракси, који су у највећем броју случајева усаглашени са међународним обрасцима, примењиваним у утицајним светским језицима. ${ }^{11}$ Поред програмираног скраћивања, Правопис оставља могућност и за слободно скраћивање, уколико се „води рачуна да скраћенице у одређеном контексту буду јасне и недвосмислене” (Пешикан, Јерковић, Пижурица, 150, т. 183). Правопис препоручује рационално и оправдано скраћивање, којим се не губи значење речи, а остварује уштеда у простору и времену.

Према начину настајања Правопис разликује следеће групе скраћеница: onште (домаће) скраћенице, мерне и опште међународне скраћенице, верзалне скраћенице (акроними) и вербализоване скраћенице.

\section{5. Истраживање: Језички знак у дигиталној комуникацији младих}

\section{1. Ранија истраживања}

Истраживањем објављене литературе и интернет извора установљено је да је у Републици Србији 2015. године обављено истраживање чији је циљ био утврђивање одступања од језичке норме у свакодневној дигиталној комуникацији младих. ${ }^{12}$ Није се дошло до података о испитивању употребе скраћеница у дигиталној комуникацији адолесцената. У актуелној научној литератури такве скраћенице се означавају као „дигиталне скраћенице” и „нетрадиционалне скраћенице" (Тарло 2011; у: Зарић 2016: 109).

${ }^{11}$ Латински, енглески, француски, руски, немачки, шпански и италијански.

${ }^{12}$ У оквиру пројекта „Јачање медијске писмености” и Кампање за медијску писменост Министарства културе и информисања, израђена је кратка експертска анализа 25 интернет страница чији су покретачи и корисници средњошколци (форуми, Фејсбук, Јутјуб, блогови, средњошколски веб-сајт). Анализиране су следеће категорије: употреба емотикона, писање речце „не” уз глаголе и придеве, писање скраћеница, употреба безличног глагола „требати” и помоћног глагола „бити”, писање великог слова, речца ,је л”" и ,јер”, знакова интерпункције, мултипликација самогласника у речима. Од укупног броја прегледаних садржаја, $75 \%$ садржи неко одступање у правопису, међу њима око $7 \%$ тзв. „дигиталних скраћеница”, попут „вдм вчрс” („видимо се вечерас”), „мсм” (,мислим”). Слична је и фреквенција заступљености нетрадиционалних скраћеница (17\%) у коментарима на Јутјуб интернет страници (Зарић 2016: 108). 


\section{2. Циљ истраживања и хипотезе}

Циљ истраживања је утврђивање обележја језичког знака младих у дигиталној комуникацији. Претпостављамо да ће истраживање потврдити следеће хипотезе:

5.2.1. Језички знак који показује највећу учесталост употребе у дигиталној комуникацији адолесцената су скраћенице.

5.2.2. Скраћенице у дигиталној комуникацији младих воде порекло из енглеског језика (у већој мери) и српског језика (у мањој мери).

5.2.3. При скраћивању речи врши се поступак почетног скраћивања и поступак сажетог скраћивања.

5.2.4. Скраћенице у дигиталној комуникацији адолесцената не прате језичку норму.

5.2.5. Промене језичког знака у савременој дигиталној комуникацији односе се на измене означитеља.

\section{3. Узорак истраживања}

Испитивање је изведено на узорку од 30 испитаника. Узорак је имао следеће карактеристике:

Старосно доба испитаника је од 18 до 19 година, у стручној литератури категоризовано као „старији адолесценти”.

Према полу, узорак је сачињавало 15 испитаника женског пола и 15 испитаника мушког пола.

Према образовању, узорак је сачињавало 30 испитаника четвртог разреда Пете београдске гимназије, друштвено-језичког смера.

\section{4. Инструмент истраживања}

Групни интервју информативног карактера обухватио је следећа питања: У чему се разликује куцуање дигиталних порука које међусобно размењујете, у односу на поруке које пишете на папиру? ${ }^{13}$ Које речи најчешће користите када се дописујете са врињацима?

Упитник који је коришћен састоји се из три дела:

У првом делу упитника прикупљени су подаци који се односе на пол, образовање и године старости испитаника.

Други део упитника чини питање отвореног типа, чији је циљ утврђивање скраћеница са високим степеном употребе у дигиталној комуникацији младих. Испитаницима је остављено довољно простора за одговор.

Трећи део упитника чини израз захвалности за учешће у истраживању.

\footnotetext{
${ }^{13}$ Као полазна претпоставка узета је чињеница да постоји разлика између дигиталне и писане поруке у комуникацији младих.
} 


\section{5. Спровођење истраживања}

Техником групног интервјуа информативног карактера, на групи од десет испитаника, утврђено је да је скраћивање речи у дигиталној комуникацији младих уобичајен поступак, као и да су скраћенице најфреквентније употребљивани облици речи. Групни интервју претходио је упитнику.

Истраживање је спроведено 23. децембра 2016. године у Петој београдској гимназији. Упитници су давани индивидуално. Одговори су давани анонимно. Примењен је метод намерног узорка одређене социјалне групе, због чињенице да ученици четвртог разреда у великој мери користе дигиталне медије у комуникацији.

С обзиром на чињеницу да стандарди постигнућа ученика за наставни предмет Српски језик и књижевност подразумевају и стицање и проширивање знања о скраћеницама у српском језику, као и правилима њиховог писања, истраживања су реализована током наставе Српског језика и књижевности. Резултати су употребљени за даља истраживања у области Методике наставе српског језика.

Ученицима је представљен циљ, научни карактер и вредност истраживања. Претпоставља се да није постојао проблем искрености испитаника.

\section{6. Резултати истраживања и њихово тумачење}

Истраживање апсолутно није указало на разлике у одговорима између полова, па унети резултати обухватају оба пола. У наредним табелама дат је преглед доминантних општих скраћеница које воде порекло из српског и енглеског језика, чији је поступак скраћивања: а) сажето скраћивање и б) почетно скраћивање. Резултати су дати према фреквентности појављивања, од најфреквентнијих, до најмање фреквентних.

Табела бр. 1: Дигитална комуникаџија младих - доминантне опште (сажете) скраћенице које воде порекло из српског језика

\begin{tabular}{|l|l|l|}
\hline Скраћена реч & Цела реч/ израз & Учесталост \\
\hline нмг & не могу & $30-35 \%$ \\
\hline мжд & можда & $25-30 \%$ \\
\hline одгми & одговори ми & $20-25 \%$ \\
\hline вчрс & вечерас & $10-12 \%$ \\
\hline нзнм & не знам & приближно 5\% \\
\hline врв & вероватно & приближно 4\% \\
\hline
\end{tabular}




\begin{tabular}{|l|l|l|}
\hline брт & брате & приближно $3 \%$ \\
\hline дбр & добро & приближно $2 \%$ \\
\hline бзвз & безвезе & приближно $1 \%$ \\
\hline
\end{tabular}

Вишечлани појмови који чине једну акценатску целину, при скраћивању се третирају као једночлани, па је принцип скраћивања сажето скраћивање (уп. „одгми” према „одговори ми”, наспрам „лн” према „лаку ноћ”). Редукција се потврђује и у изостављању размака између чланова истог израза.

Иако се опште скраћенице завршавају тачком, у језичкој пракси младих у дигиталној комуникацији, тачка се никада не пише. Ова чињеница може се објаснити потребом за уштедом времена и простора адресата.

Избор скраћеница указује на уобичајени предмет поруке у интерперсоналној комуникацији младих (кратак одговор на постављено питање, одбијање, прихватање, захтев да се комуникација настави или прекине и сл.).

Табела бр. 2: Дигитална комуникаиија младих - доминантне опите (почетне) скраћенице које воде порекло из српског језика

\begin{tabular}{|l|l|l|}
\hline Скраћена реч & Целареч/израз & Учесталост \\
\hline поз & поздрав & $30-35 \%$ \\
\hline лн & лаку ноћ & $20-25 \%$ \\
\hline нисс & ништа & $20-25 \%$ \\
\hline љуб & љубим те & $20-25 \%$ \\
\hline ћ & ћао & приближно 5\% \\
\hline хв & хвала & приближно 5\% \\
\hline
\end{tabular}

Енглеска тастатура условила је да скраћивање речи „ништа” гласи „нисс” (латиничко „s” ум. ћириличког „ш”). 
Табела бр. 3: Дигитална комуникација младих - доминантне опште (сажете) скраћенице које воде порекло из енглеског језика

\begin{tabular}{|l|l|l|l|}
\hline Скраћена реч & Цела реч/ израз & Значење & Учесталост \\
\hline sth & something & нешто & $20-25 \%$ \\
\hline rlu & realy & стварно & $15-20 \%$ \\
\hline gf & girlfriend & девојка & $15-20 \%$ \\
\hline bf & boyfriend & момак & $15-20 \%$ \\
\hline Y & Why? & Зашто? & $10-15 \%$ \\
\hline bby & Bay, bay! & Збогом! & $10-15 \%$ \\
\hline
\end{tabular}

Потреба за економичношћу и минималним бројем карактера условила је скраћивање речи на доминантне консонанте. Интересантан је резултат који показује да је један самогласник заменио целу реч („Y” наспрам „Why?”). Веза између конвенционално утврђеног означитеља и новонастале скраћенице, остварена је финалним самогласником, који је истовремено и једини самогласник у речи.

Табела бр. 4: Дигитална комуникаиија младих - доминантне опите (почетне) скраћенице које воде порекло из енглеског језика

\begin{tabular}{|l|l|l|l|}
\hline Скраћена реч & Цела реч/ израз & Значење & Учесталост \\
\hline Idk & I don't know & не знам & $15-20 \%$ \\
\hline lol & laughing out loud & гласан смех & $15-20 \%$ \\
\hline Idc & I don't care & не занима ме & $10-15 \%$ \\
\hline np & no problem & нема проблема & $10-15 \%$ \\
\hline gtk & got to know & морам да знам & $10-15 \%$ \\
\hline у & уou/ yes & ти/ да & $5-10 \%$ \\
\hline wp & well played & добро одрађено & $5-10 \%$ \\
\hline gj & good job & добар посао & $5 \%$ \\
\hline ttyl & talk to уоu later & чућемо се касније & $2-5 \%$ \\
\hline
\end{tabular}




\begin{tabular}{|l|l|l|l|}
\hline ofc & of course & наравно & $2-3 \%$ \\
\hline $\mathrm{jk}$ & just kidding & само се шалим & $2-3 \%$ \\
\hline brb & be right back & вратићу се & $2-3 \%$ \\
\hline ly & (I) love you & волим те & $2-3 \%$ \\
\hline lysm & $\begin{array}{l}\text { (I) love you so } \\
\text { much }\end{array}$ & много те волим & $2-3 \%$ \\
\hline rn & right know & одмах & $2-3 \%$ \\
\hline imo & in my opinion & по мом мишљењу & $1-2 \%$ \\
\hline btw & by the way & између осталог & $1-2 \%$ \\
\hline bff & best friends forever & $\begin{array}{l}\text { најбољи пријатељи } \\
\text { заувек }\end{array}$ & $1-2 \%$ \\
\hline asap & as soon as possible & што пре & $1-2 \%$ \\
\hline onl & on line & на вези & приближно $1 \%$ \\
\hline hf & Have fun! & Забави се! & приближно 1\% \\
\hline
\end{tabular}

\section{7. Закључци истраживања}

На испитаној групи утврђено је да су скраћенице језички знак који показује највећу учесталост употребе у дигиталној интерперсоналној комуникацији младих. Скраћенице у дигиталној комуникацији адолесцената воде порекло из енглеског језика, у већој мери, и, у мањој, из српског језика. Доминантан принцип скраћивања речи из енглеског језика је почетно скраћивање, док су код речи које воде порекло из српског језика подједнако присутна оба поступка скраћивања - и почетно и сажето скраћивање. Одговор се може наћи у чињеници да енглески правопис није фонетски, па словни почетак куцане (написане) речи или израза штити језички знак од декодирања.

Потврђена је хипотеза да су промене на језичком знаку у дигиталној комуникацији извршене на нивоу означитеља.

\section{6. Закључак}

Савремене варијанте бивше епистоларне праксе - вајбер и Ес-Ем-Ес поруке, блогови и коментари на социјалним мрежама, у дигиталној култури представљају ново медијско поље за изградњу сопственог идентитета и везе са 
спољним светом. Технологије су постале и социјални и културолошки алати, њихово значење одраз је и презентовања себе и комуникацијски ритуал савременог доба.

У таквом дигиталном окружењу језички знак наилази на одређене промене, које се огледају у његовој инсуфицијенцији. Исход ове промене је интензивирање процеса економичности, селективности, редукције и скраћивања речи. Трансформација означитеља језичког знака одвија се у смеру кршења језичке норме и слабљењу везе са некадашњим означитељем. Скраћенице су преузеле доминацију у дигиталној интерперсоналној комуникацији младих услед потребе за уштедом времена и простора, као и технолошке ограничености да се порука изрази у одређеном броју карактера. Скраћенице у дигиталној комуникацији на српском језику воде порекло из енглеског и српског језика. Скраћивање се одвија на два начина - као почетно и као сажето скраћивање речи. Доминантни гласови у новонасталим скраћеницама су консонанти. Промене извршене на језичком знаку показатељ су језичке и културне еволуције.

Жан-Жак Русо (Jean-JacquesRousseau) је веровао да су првобитни језици били „певачки и страствени” („,chantantes et passionnées”), пре него што су постали „поједностављени и методични” (,simples et méthodiques”) ${ }^{14}$. Поједностављивање о коме Русо говори очигледно је у кодирању језичког знака у дигиталном окружењу. Претпостављамо да велики француски мислилац није имао у виду да ће демократско либерално друштво поред „поједностављивања” језика истовремено донети и слабу конвенцију која све мање обавезује и тежи да „превазиђе” методичност. Да ли је, у том случају, било који језик икада достигао Фукоов (Foucault) идеал да буде у потпуности поуздан и јасан знак ствари које обележава? Тенденције развоја дигиталне културе указују да ће процес трансформације дигиталног дискурса тек показати своје исходе.

\section{ЛИТЕРАТУРА}

Гиро 1975: П. Гиро, Семиологија, Београд: Бигз.

Зарић 2016: Ј. М. Зарић, Утицај нових медија на језик у дигиталном окружењу, Београд: Кюижевност и језик, LXIII 1-2, Београд, 107-112.

Зипф 1949: Zipf G. K., Human Behavior and the Principle of Least Effort, Cambridge/Mass.

Јакобс, Розенбаум 1971: R. A. Jacobs, P. S. Rosenbaum, Transformation, Style and Meaning, Mass: Xerox College Pub.

Јакобсон 1988: Р. Јакобсон, Темељи језика, Загреб: Глобус.

${ }^{14} \mathrm{http} / / /$ www.ac-grenoble.fr/PhiloSophie/ 
Кецман, Милошевић, Ћећез-Иљукић 2013: В. Кецман, Ј. Милошевић, Д. Ћећез-Иљукић, Граматика српског језика за први разред гимназија и средњих стручних школа, Београд: Нови Логос.

Лајонс 1983: Layons, Semantik, Bd. II, Munchen.

Мартине 1973: А. Мартине, Језик и функиија, Сарајево: Свјетлост.

Пешикан, Јерковић, Пижурица 2010: М. Пешикан, Ј. Јерковић, М. Пижурица, Правопис српскога језика, Нови Сад: Матица српска.

Симић 1991: Р. Смић, Увод у филозофију стила, Сарајево: Свјетлост.

Тарло, Мрочек 2011:C. Thurlow, K. Mroczek, Digital Discourse Language in the New Media, Oxford: Oxford Studies.

Фуко 1971: М. Фуко, Ријечи и ствари, Београд: Нолит.

Интернет извор:

Rousseau, J. J., Essai sur l'origine des langues. Profil Textes Philosophiques: édition électronique. http://www.ac-grenoble.fr/PhiloSophie/, посећено 12. марта 2017.

Violeta R. Kecman

TRANSFORMATION LINGUISTIC SIGN IN DIGITAL COMMUNICATION ADOLESCENTS

Summary

Because of grapheme conditionality and enabling new information technology, digital communication provides an opportunity for ordinary everyday person to participate in the creation of linguistic signifiers of the sign which it is used. Unplanned and without the conscious will, on a daily basis gets ,that challenged the global platform of the new digital media confirm their presence in a given historical moment.In the digital environment reeds sign encountering some changes, which are reflected in its failure. The outcome of these changes is an intensification of process efficiency, selectivity, reduction and shortening words. The transformation of signifiers of linguistic signs takes place in a direction violation of linguistic norms and weakening ties with former signifier.Abbreviations have assumed dominance in the digital interpersonal communication of adolescents, due to the need to save time and space, as well as technological limitations that the message expressed in a certain number of characters. Abbreviations in digital communication in Serbian language descended from English and Serbian languages. Shortening occurs in two ways - as a start and as concisely shorten words. The dominant in the 
new abbreviations are consonants. Changes made on the tab marked indication of the linguistic and cultural evolution. In the conducted empirical research with students Peta beogradska gimnazija confirmed that the changes in the linguistic sign in digital communication carried out at the level of the signifier.

Key words: linguistic sign, digital communications, digital media, abbreviations, insufficiency, adolescents. 